\title{
Teaching English for Medical Purposes: How to Embrace THE Challenge
}

\author{
Edita Drozdová \\ Technical University of Liberec, Faculty of Economics, Department of Foreign Languages, \\ Studentská 1402/2, 46117 Liberec 1, Czech Republic \\ e-mail: edita.drozdova@tul.cz
}

\begin{abstract}
The article deals with ESP (English for Specific Purposes), in particular EMP (English for Medical Purposes) and explains the thorniest problems both the teacher and the student encounter in Medical English language courses. In the first part, the major challenges are focused on and analysed. Firstly, based on a placement test, multilevel classes are illustrated. Secondly, medical terminology and the most common vocabulary and pronunciation mistakes are pinpointed. And thirdly, the lack of usable up-to-date study materials is mentioned and the assets of e-learning are emphasized. In the second part of the article, with reference to a survey and its respondents' comments, the role of an ESP teacher is discussed.
\end{abstract}

\section{Keywords}

EGP; ESP; EMP; Heterogeneity; Terminology.

\section{Introduction}

In ESP (English for Specific Purposes), namely EMP (English for Medical Purposes), there are numerous challenges both teachers and students have to face, e.g. heterogeneity of classes, specific terminology, lack of usable and up-to-date textbooks (therefore the necessity for teachers to prepare their own ones and search for suitable on-line materials to keep up with the remarkable progress in medical science and technology), and a limited length of courses.

According to Tom Hutchinson and Alan Waters Lancaster [1], "ESP is an approach to language teaching which aims to meet the needs of particular learners." Using an analogy of a tree, they demonstrate that ESP is just one branch of EFL (English as a Foreign Language)/ESL (English as a Second Language) and explain what ESP is not: it is not a matter of teaching specialized varieties of English, it is not a matter of science words, and it is not different from any other form of language teaching.

Thus, the two basic questions an ESP teacher should ask are what their students' needs are and how should they be met.

Many other questions arise: How to keep the balance between special and general English? Are all the language skills and their mastering of the same importance in EMP? How to motivate the students to be aware of English as Lingua Franca and its role in their future (not only professional) life? How to encourage them to keep boosting the language after they finish the course?

And, last but not least, there is the crucial question: Who should teach ESP? A language teacher or a professional in the field? Is it possible for a non-native language teacher to tackle this task? 
Basturkmen [2] points out that teachers often find themselves dealing with content in an occupation or subject of study that they themselves have little or no prior knowledge of. This represents one of the biggest ESP challenges.

Hutchinson and Waters [1] expressed this issue quite poetically: teachers are "all too often reluctant dwellers in a strange and uncharted land".

It is beyond any doubt that role of a (not only ESP) teacher is to be a mediator between the language and subject knowledge by providing language needed to express the content [3] and that their most important objective should be helping students to learn and encourage them to deepen and broaden their language skills on their own - even outside the classroom and after they finish their university language course.

In its first part, the article looks at the thorniest problems and common mistakes to be dealt with in ESP/EMP courses. The second part analyses results of a survey and attempts to discuss by whom and how English for Specific Purposes should be taught.

\section{$1 \quad$ Research Objective}

The purpose of the research was to summarize the problems and challenges of teaching and studying EMP (English for Medical Purposes) in a four-semester course.

An important goal was to investigate the language levels of ESP courses students and the multilevel classes' impact on ESP teaching. On the basis of a placement test, the approximate language levels have been revealed.

The article aims at identifying the major problems faced in ESP courses, namely heterogeneity of classes, specific terminology, lack of usable available up-to-date study materials (course books) and a limited length of courses.

Further, based on a survey, the role of an ESP teacher is discussed and indicated.

\section{$2 \quad$ Research Methods}

Proceeded from empirical teaching experience and personal observation records and taking into consideration the students' performance during lessons from the first semester up to the forth one, results of credit tests and the Final Oral Exam, the author's evaluations and conclusions are drawn and the most common mistakes made in Medical Terminology, including pronunciation and confusable words and structures, are listed.

Based on a placement test in Lesson 1, Semester One, the levels of English in students of EMP courses have been identified and processed into graphs.

On the basis of the author's on-line survey, the opinions of a group of 173 respondents on whether a Language Teacher or Professional in a particular field makes an ideal ESP teacher are processed into graphs, their notes states and the ESP teacher's role is discussed.

\section{The Challenges of ESP/ EMP}

Regardless of their profession, education or teaching ability, an ESP teacher has to face many challenges and map out their strategies. The same applies to the students: being users of such a minor language as Czech, and if really interested in their future careers, they should be aware of the fact that English as a language of international communication, Lingua Franca, is essential in their future (not only professional) life.

The major challenges both teachers and students have to tackle and embrace in English for Medical Purposes courses are focused on in the following paragraphs. 


\subsection{Heterogeneity of Classes}

At the beginning of the Academic Year 2019/20, "Quick placement test" [4] was handed out in order to determine approximate (as based on Use of English multiple choice questions, i.e. Speaking, Listening, Writing skills were not included) level of the Faculty of Health Studies TUL Year One students attending the author's ESP/EMT courses: General Nurse, Paramedic and Biomedical Technician.

According to CEFR standard (Common European Framework of Reference for Languages) [5], the six reference English levels, which are widely accepted as the global standard for grading an individual's language proficiency are:

- English Basic User (A1, A2)

- A1 (Beginner)

- A2 (Elementary English)

- English Independent User (B1, B2)

- B1 (Intermediate English)

○ B2 (Upper-Intermediate English)

- Proficient English User (C1, C2)

○ C1 (Advanced English)

○ C2 (Proficiency English).

The test results are shown in Figure 1.

\section{Level of English}

(Year One Students at the Faculty of Health Studies)

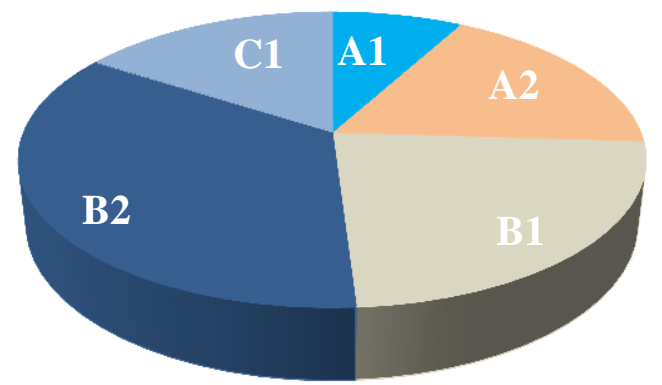

Source: Own

Fig. 1: Level of English, Year One Students at FHS

None of the students' level was A0 nor C2; at first sight the result is highly optimistic:

A1: $8 \%$

A2: $18 \%$

B1: $23 \%$

B2: $35 \%$

C1: $16 \%$

However, during the first, introductory, lesson it was found out that only a tiny number of students in any course showed at least minimal knowledge of medical language, e.g. none of those first grade (188) students could name as little as 3 medical professions, illnesses or procedures with a correct pronunciation. 
A survey was held by the author in all groups, investigating How many students have taken their Final Leaving Examination "Maturita" at their secondary schools.

The result is shown in Fig. 2.

Final Secondary School Leaving Exam "Maturita"

(Year One Students at the Faculty of Health Studies)

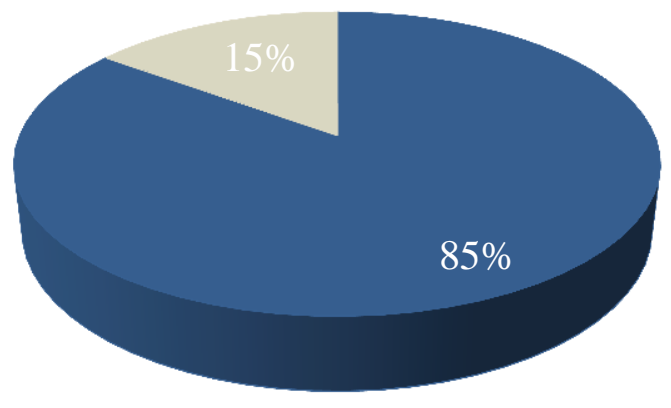

QYES NO

Source: Own

Fig. 2: Final Leaving "Maturita” Exam, Year One Students at FHS

$85 \%$ of students opted for English instead of mathematics, and successfully passed the finals including General English Exam. Approximately $15 \%$ of the total number of students studied at Secondary Medical Schools. They stated that the exam did contain some Medical English questions, but only quite general ones - e.g. Human Body, Health or Florence Nightingale (the founder of Nursing).

Dealing with heterogeneity classes, or multilevel/ mixed is rather a common issue throughout EFL, not only in ESP. Numerous studies have been written on this topic, seeking possible strategies and suggesting solutions. Penny Ur [6], for example, analyses heterogeneous classes identifying and listing problems such as assignments, interest, effective learning for all, materials, individual awareness or participation.

A clever, witty and inspirational article on strong strategies to teach different levels of ESL students was recently written by Kristimarie [7].

\subsection{Terminology - Similarity Purely (Non) Accidental}

Obviously, teaching and studying terminology in ESP/EMP courses is important, but not of critical importance. Some might argue with this statement; nevertheless - as emphasised further - it is always the balance to be kept as far as all language skills are concerned and teaching/ studying in context is crucial in ESP.

What is more, specific terminology can be quite successfully self-studied.

Nevertheless, specific terminology in Medical English does represent a thorny, not an easily manageable challenge. The pitfall students tend to fall in is the fact that they often DO KNOW an expression/term commonly used in medical Czech/Latin terminology. However, the pronunciation AND spelling is usually (often only slightly, which makes it even more tricky) different in English. 
This paragraph does not aim at a detailed linguistic analysis but rather attempts to pin-point the trickiest issues and common mistakes made by Czech users of medical terms and vocabulary, as observed and recorded by the author during her personal empirical teaching experience.

Approximately 95\% of English terms are borrowed from or created on the basis of Latin and Latinised Greek [8]. Anglicized Latin, in which words are pronounced as if they were English words, often represents a huge problem in Medical English comprehension causing mutual (native - non-native users) misunderstanding.

Typical anglicized Latin terms are "muscle," "vein," or "nerve".

In Table 1 selected frequent medical terms which are similar to the ones students know and use have spelling and pronunciation different from Czech and therefore represent problems.

Tab. 1: Selected Medical Expressions (similar to Czech but with different spelling and pronunciation)

\begin{tabular}{|l|l|}
\hline Czech & English \\
\hline anesteziolog, kardiolog, radiolog, atd. & anaesthetist, cardiologist, radiologist, etc. \\
\hline fyzioterapeut & physiotherapist \\
\hline dentista & dentist \\
\hline pediatr & paediatrician \\
\hline autismus & autism \\
\hline artritida & arthritis \\
\hline bronchitida & bronchitis \\
\hline neurologie, patologie, oftalmologie, atd. & neurology, pathology, ophthalmology, etc. \\
\hline pediatrie & paediatrics \\
\hline terapie & therapy \\
\hline mamografie & mammography \\
\hline atd. & etc. \\
\hline
\end{tabular}

Source: Own

\subsubsection{Pronunciation: Tricky Speech Sounds}

- EA
○ /ıә//з:/ /e/ /i:/ /eә/ /ei/ /a:/
- breath /e/ vs. breathe /i:/
- tear /eə/ vs. tear/ı/
- clean/iə/vs. cleanse /e/
- heat /i:/ vs. head /e/
- hear/ı/ vs. heard/3:/

- BI (meaning two or double) - bipolar, bilateral, bifacial /bai/vs. bigamist/bi/

- $\mathrm{G}: / \mathrm{g} / \mathrm{vs} . / \mathrm{d} z /$
○ The general rule for the pronunciation of $\mathrm{G}$ : if the following letter 'e', ' $i$ ' or ' $\mathrm{y}$ ', the pronunciation is $/ \mathrm{d} 3 /$.
- However, there are many irregularities and many of these tricky g-s appear in medical terminology.
○ Examples:
- gynaecology and other 'gyn-' words, gear, giga, give, finger, hunger, stagger, trigger /g/
- abridgment, suggest, veggies /dz/

- H vs silent letter (words borrowed from French)

○ a hospital but an hour /'hospit(ə)1/ vs /'avə/ 
- $\mathrm{HI}, \mathrm{HY}$

- hippo /'hıpəo/ (a prefix from the Greek word for horse.) - hippotherapy, hippocampus (a part of the brain, sea horse)

- hyper /'hııрә/ and hypo /hııрә/ (hyper- is a prefix that means excess or exaggeration, while hypo- is a prefix that means under or beneath. Hyper is derived from the Greek word for over, and hypo is a Greek word that means under.

- $\mathrm{CH}$ - there is no such sound in English, it is either / $\mathrm{k} /$ (technical) or $/ \mathrm{t} f /$ (chest)

- $\mathrm{OO}$

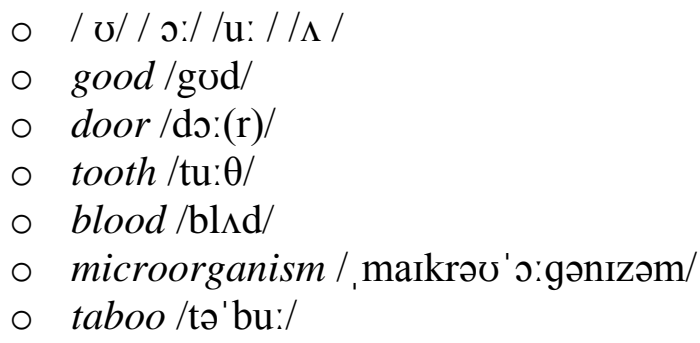

\subsubsection{False Friends}

The informal term false friends - a typical phenomenon in many languages - refers to pairs of words that have the same or similar spelling and/or sound but have (very often a totally!) different meanings in two languages.

In Table 2, the most common false friends Czech students of Medical English have to be aware of are listed.

Tab. 2: False Friends

\begin{tabular}{|c|c|}
\hline English & Czech \\
\hline actual & skutečný \\
\hline ambulance vs out patient & sanitka vs. ambulantní pacient \\
\hline check vs. control & kontrolovat (stav) vs. kontrolovat (řídit, ovládat) \\
\hline disabled vs. invalid & postižený vs. bezcenný \\
\hline exposition vs. exhibition & vystavení (vlivu) vs. výstava \\
\hline hand vs. arm & ruka (po zápěstí) vs. paže \\
\hline leg vs. foot & noha vs. chodidlo \\
\hline $\begin{array}{l}\text { prescription vs. recipe vs. } \\
\text { receipt }\end{array}$ & předpis od lékaře vs. recept na vařeni vs. doklad \\
\hline $\begin{array}{l}\text { promotion vs. graduation } \\
\text { ceremony }\end{array}$ & povýšení vs. promoce \\
\hline sensitive vs. sensible & citlivý vs. rozumný \\
\hline finger vs. toe & prst na ruce vs. prst na noze \\
\hline thumb vs. big toe & palec (na ruce) vs. palec (na noze) \\
\hline$X$-ray vs. Roentgen & $\begin{array}{l}\text { rentgen (prístroj) vs. fyzikální jednotka vs. Wilhelm Conrad } \\
\text { Röntgen, objevitel záreni }\end{array}$ \\
\hline etc. & atd. \\
\hline
\end{tabular}

Source: Own

Why is all this so important? Well, to put it simple: native English (as a world language) speakers simply WILL NOT understand you when you do not speak correctly in this aspect. Czech people, in contrast, as users of a minor language, are better at accommodating in communication with foreigners. Common native English language speakers' (including medical professionals') phonetic imagination and willingness to understand usually counts to 
zero (if not for a teacher or somebody meeting foreigners on daily work basis and thus forced to try and spare no effort to understand). These people are exceptions proving the rule. It seems to be quite important in health care communication, does it not?

\subsection{Lack of Usable and Up-to-Date Study Materials}

Given the fact that nowadays publishing textbooks is not very economically profitable, it is very difficult to find suitable and modern textbooks that meet the requirements of effective ESP teaching. Most of the available titles are obsolete and often almost useless for our purposes.

Actually, the progress in science and technology is so enormous that no publisher is to blame for their hesitation: what applies in medical science today will most probably be out of date tomorrow. It seems that with the abundance of the infinite Internet information and easy access to countless sources the teacher has no problem to find suitable teaching materials.

The necessity for teachers to search for suitable on-line materials, adapt them and to prepare their own ones is obvious; nevertheless it is extremely time consuming and fiddly work: for example, to find a video neither too long nor too short preferably with English subtitles, an article of the appropriate level and satisfactory content etc. for each topic.

E-learning environment becomes a bank utilizing these carefully selected links, tips and teacher's adapted and own materials during lessons and - most importantly - helping students in self-studies at home.

Not only most useful professional/ medical links should be found in e-learning courses, but also - and quite importantly - tips and links for practising Use of English, watching films including medical dramas, listening, reading and all other sorts of inspirational miscellaneous materials helping the young audio-visual generation to boost their English and make them love and enjoy the language.

\section{$4 \quad$ Who Should Teach ESP?}

To give an unequivocal answer to this extremely difficult question is basically impossible: there is no "correct" or generally applicable answer. ESP teaching and studying should always be kept in perspective. The ESP teacher's point of view might be dramatically different from the student's one; other factors play important roles as well: requirements of the particular faculty/ department, utilization of the foreign language in students' future professional career (if it is "sine qua non") or just a bonus, etc.

\subsection{Survey}

In October 2019, an on-line survey was carried out by the author in a group of 173 respondents consisting of language teachers; academics, scientists and non-language teachers; and university students.

There was only one simple question, offering two options, a, or b. Without any further request for listing details, explaining or justifying their opinions, the respondents were asked to "answer without long hesitation" "Should ESP by taught by (a) language teacher, (b) a professional in the field?"

The results of the survey are shown in Figures 3, 4, 5 and 6. 


\section{All Survey Respondents' Opinion}

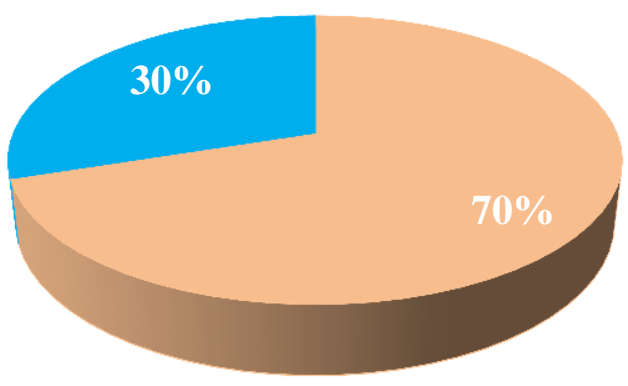

Language Teacher Professional in the Field

Source: Own

Fig. 3: Who should teach ESP: total number of all survey respondents' answers

\section{Language Teachers' Opinion}

\section{$20 \%$}

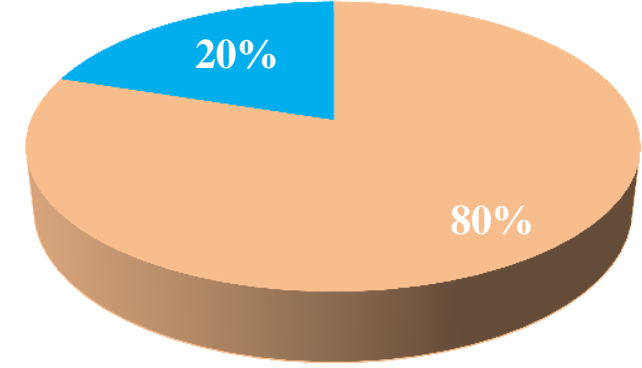

Language Teacher $\quad$ Professional in the Field

Source: Own

Fig. 4: Who should teach ESP: language teachers' answers

\section{Academics, Scientists and Non-language Teachers' Opinion}

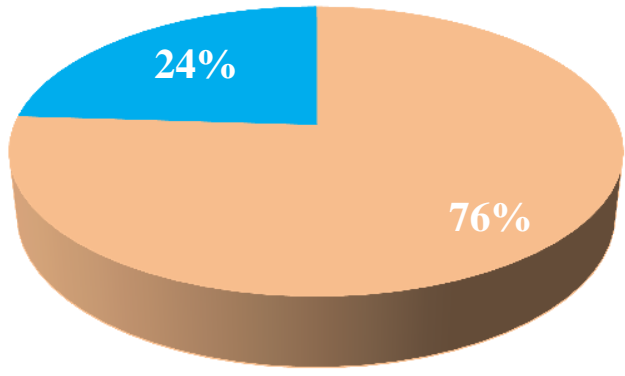

Language Teacher Professional in the Field

Fig. 5: Who should teach ESP: academics, scientists and non-language teachers' answers 


\section{University Students' Opinion}

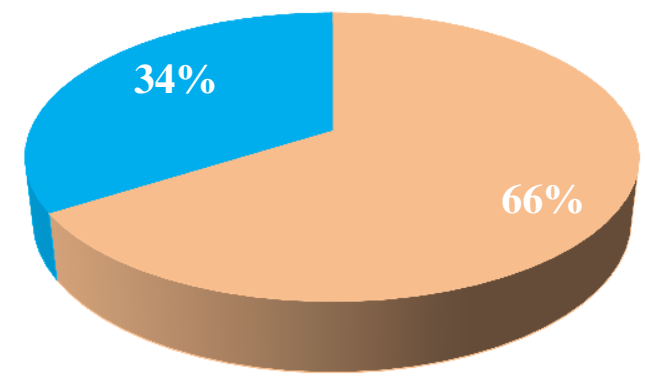

Language Teacher Professional in the Field

Source: Own

Fig. 6: Who should teach ESP: students'answers

The total all survey participants opinion is $70 \%$ to $30 \%$ in favour of a Language Teacher.

Language teachers' opinion result, not surprisingly, revealed that most of them are aware of what they do and that they are mostly convinced they do it well being capable of handling their task successfully ( $80 \%$ to $20 \%$ ).

In academics, scientists and non-language teachers the gap becomes wider ( $76 \%$ to $24 \%$ ) but still much in favour of a Language Teacher who, in their opinion, is able to handle teaching ESP better.

University students' opinion, however, widens the gap most significantly (66\% to 34\%). Whilst a Language Teacher still being preferred, the numbers do show quite a shift from the nearly unanimous opinion of their (existent or potential) language teachers and reveal the fact that they do respect Professionals in their field and often would prefer - for a number of reasons - them to be their ESP teachers. Vox populi, vox Dei!

Despite the fact that the respondents were not explicitly asked to justify their opinion, there were some very interesting comments worth quoting (given the limited space of this article, they are left without any further comments or analysis and chosen at random). The respondents' statements conclude the following paragraphs.

\subsubsection{The Language Teacher}

The language teacher should be knowledgeable enough in the field. A question arises: "What does 'knowledgeable' enough actually mean?" A language teacher is not (in our case) a doctor, a nurse, a paramedic or a biomedical scientist. Some offer the attitude "I am not an expert but a language teacher." or "I am not a walking dictionary." - neither of which, in the author's humble opinion, holds water. Firstly, the ESP teacher should never provide students with materials / exercises / articles / videos the terminology of which they are not familiar with or have examined closely. Secondly, it is a must for an ESP teacher to keep up with the progress in science and technology in the particular field. If they stick to the above mentioned excuses and their knowledge of the specific field is totally deficient, their ESP teaching will never be of a high quality. In other words, general language is not enough for ESP. Obviously, numerous situations occur (especially when discussing a specific issue or taking tricky questions) in which you simply do not know because you are not and obviously can never be an expert in the field. Such situations are common and should be handled in all 
honesty and modesty: it is not a shame to admit "I don't know.", or alternatively to offer the students "It is my homework." answer, or, a bit mischievous, but if delivered with love and encouragement, a cordial and stimulating reply "What an interesting question! Could you please look it up and tell us next lesson?" Eventually - of course - it is always possible to "google it" and at the same time show students how to do it quickly!

It is more than clear that an ESP teacher should be - at least - a fan of the particular field. Being extremely time demanding, ESP teaching should focus on one, maximum two fields. We should be aware of the truthfulness of the figure of speech that "Jack of all trades is master of none."!

In spite of the fact that the respondents were asked to try and choose without further hesitation either a) language teacher or b) professional in the field answer to the question Who should teach ESP?, there were some very interesting comments justifying and explaining their chosen option.

\section{Notes by respondents who opted for (a) Language Teacher:}

...based on my experience, definitely a language teacher.

Professional language is primarily a question of vocabulary. And if the aim of teaching is to master a language and not to teach a field in a foreign language then the answer is obvious.

Without hesitation I would say a language teacher.

A linguist, of course, because I think that the person simply "must know a foreign language" i.e. to pass it on, in a lapidary way. However, it is assumed that they must penetrate the terminology at least in part in terms of content.

The very nature of the question implies that a TEACHER TEACHES.

In principle and without long hesitation: a language teacher.

The language is to be taught, albeit terminologically focused on.

An expert in the field would want us to know too much...

As a linguist, the teacher will teach the "few" vocabulary we need and can explain it better.

Teacher linguist will rather have the gift to pass on knowledge

A professional uses difficult words and phrases and does not explain them - it is hard for students.

Learning vocabulary is easy, but grammar needs to be properly explained, and I believe a linguist more in this respect.

Teacher is a linguist because he has pedagogical education, he knows how to teach and what to teach...

Language teachers know how to plan a lesson.

It is about passing the language and the teacher knows how to do it better...

You can learn tons of words on your own but you can't always learn the language...

\subsubsection{The Professional in the Field}

Whether a professional in the field could make a good ESP teacher depends on 2 crucial factors, i.e. whether they:

a) are equipped with the language/linguistic knowledge sufficiently, and 
b) have "teaching skills" (not necessarily teaching qualification but rather the ability/talent to pass on appropriate (all) language skills ESP teaching requires to their students, bearing in mind the specifics and keeping the balance between the general and the specific language.

Let us face it: yes, indeed, there are honourable individualities who do meet these conditions. But, frankly, they are usually exceptional and quite rare. The result of the author's informal survey/discussion held in a group of academics (with different scientific field focus) who have been attending her general English language course, and who frequently deliver their presentations, write articles and communicate with their foreign colleagues in English, is that $90 \%$ believe that a language teacher can provide more useful language teaching, while terminology etc. can be handled individually and self-studied - which, vice versa, would usually be not be possible or very difficult.

On the other hand, whereas an experienced language teacher (usually) knows all linguistic aspects by heart and has pedagogical skills, a professional can present specific knowledge and share their invaluable experience with students in a way a language teacher can never do: as mentioned above, language teachers, regardless of how hard they try and big fans of the field they might be, never ever would master the particular professional field to the full.

Added to answering the requested survey question Who should teach ESP? there were some very interesting comments justifying and explaining the respondents' viewpoint, which cannot be but quoted.

\section{Notes by respondents who opted for (b) Professional in the Field:}

If a professional teaches ESP, they should be a native speaker. If they are not, a language teacher is better.

Teachers touch various topics, not only our field.

An expert in the field, who has language skills at level C1 /2, in addition the ability to pass on their knowledge.

My answer is b), but only if the specialist is proficient in the language.

Certainly, when an expert speaks a foreign language really well (e.g. staying abroad at a professional workplace) and has the "above given skills" and is able to teach it.

If a professional teaches ESP, they should be a native speaker.

Professional in the field - a native speaker or somebody with a minimum level of C1.

Professional in the field with language skills. Linguists who do not understand the problems sometimes translate nonsensically.

For me the teaching of foreign languages in the Czech Republic is inadequate and I would prefer to choose a native speaker or at least an expert in the field.

We should know at least B2 level English from the secondary school. At University, it should be professionals to teach us professional English.

A professional is better - they have a lot of experience using English from their (previous) job.

We need special English, not grammar and that stuff...

Professionals know what they are telling you. 


\subsubsection{The Native Speaker}

Beyond all doubt, being a native speaker is an asset in language teaching. Fortunately, the gate to the World behind the Iron Curtain was wide open 30 years ago, and everyone who desires and decides to teach English as a foreign language has the opportunity to master Lingua Franca. Thanks God, the days of teachers of Russian as a compulsory language in the Czechoslovakian Socialist Republic who had to switch to English and were often one unit ahead of their students in a textbook are over.

But still, according to generally accepted notion based on numerous studies and research worldwide, unless having studied and reached a decent level of a foreign language until the age of 12 , nobody can master a foreign language completely and absolutely.

A native speaker is, has been and will always be a true and genuine representative of Language Two / Foreign Language teacher.

However, not all native speakers are teachers (see section 4.1.1) or/and professionals in a particular field (see section 4.1.2).

What is more, an important issue in ESP is the role of Language One. Unquestionably, students need some L2 - L1 and vice versa feedback, which is very often necessary and the comparison with their mother tongue (i.e. translation of the used terminology) is crucial - and, of course quicker (i.e. when explaining/translating grammar, idiomatic phrases, "false friends" and confusable specific terminology).

It would be an extremely challenging quest for a researcher in the ESP field to investigate how many native speakers who are experts in a particular field, well equipped teachers and at the same time fluent users of their students' L1 there are in the Czech Republic!

\section{Conclusion}

Teaching and learning ESP/EMP is a challenge for both teachers and students.

According to the Collins Dictionary [9],

"A challenge is something new and difficult which requires great effort and determination."

Be it multilevel classes requiring sensible group work and individual approach, terminology with its tricky words and sounds, necessity to prepare and tirelessly search for interesting study materials, balance and harmony should always be kept.

No matter whether the ESP teacher is a linguist, a professional in the field, a native or nonnative speaker. They should observe the best of the tried and tested formulas of teaching methodology, keep the balance between general and specific, common and extraordinary, view things in context and try hard to manage to get the best of both worlds.

They should respect the student, never punish them with unfulfillable tasks, be modest and fair, open to new ideas and willing not only to teach but to learn from their students, would-be professionals in the field.

All things are connected, one leads to another.

Learning through mistakes should be everyone's credo.

ESP is a challenge not only to be faced, but embraced.

Let us remember our famous Teacher of Nations, John Amos Comenius, and his words: 
"The proper education of the young does not consist in stuffing their heads with a mass of words, sentences, and ideas dragged together out of various authors, but in opening up their understanding to the outer world, so that a living stream may flow from their own minds, just as leaves, flowers, and fruit spring from the bud on a tree."

\section{Literature}

[1] HUTCHINSON, T.; WATERS, A: English for Specific Purposes. Cambridge University Press, Cambridge, 1987. ISBN 978-0-521-31837-2.

[2] BASTURKMEN, H.: Developing Courses in English for Specific Purposes. Macmillan, Basingstoke, 2010. ISBN 978-0-230-22797-2.

[3] AHMED, M. K.: The ESP Teacher: Issues, Tasks and Challenges. English for Specific Purposes World. 2014, Vol. 15, Issue 42. ISSN 1682-3257.

[4] MACMILLAN: Straightforward - Placement Tests - Quick placement test. [online]. 2019. [accessed 2019-10-10]. Available from http://www.macmillanstraightforward.com/resources/tests/

[5] COUNCIL OF EUROPE: CEFR standard (Common European Framework of Reference for Languages). [online]. 2019. [accessed 2019-10- 4]. Available from WWW: $\quad$ https://www.coe.int/en/web/common-european-framework-referencelanguages/level-descriptions

[6] UR, P.: A Course in Language Teaching. Practice and Theory. Cambridge University Press, Cambridge, UK, 1991. ISBN 978-0-521-44994-6.

[7] KRISTIMARIE: Make It Happen: 5 Strong Strategies to Teach Different Levels of ESL Students at Once. [online]. 2019. [accessed 2019-8-10]. Available from WWW: https://www.fluentu.com/blog/educator-english/different-levels-of-esl-students/

[8] LYSANETS, Y. V.; BIELIAIEVA, O. M.: The use of Latin terminology in medical case reports: quantitative, structural, and thematic analysis. Journal of Medical Case Reports. 2018. Online ISSN 1752-1947. DOI: 10.1186/s13256-018-1562-X

[9] Challenge. In: Collins Dictionary. [accessed 2019-11-10]. Available from WWW: https://www.collinsdictionary.com/dictionary/english/challenge

Mgr. Edita Drozdová 


\section{ODBORNÁ MEDICÍNSKÁ ANGLIČTINA - VÝZVA PRO UČITELE I STUDENTA}

Článek se zabývá Angličtinou pro specifické účely (ESP), konkrétně Angličtinou pro medicínské účely (EMP) a seznamuje s nejzásadnějšími problémy, se kterými se učitelé i studenti v kurzech medicínské angličtiny setkávají. První část článku se věnuje hlavním výzvám ESP. První problém představuje nestejnorodá jazyková úroveň. Víceúrovňové skupiny jsou ilustrovány na základě rozmist’ovacího testu. Zadruhé je to medicínská terminologie; článek vyjmenovává a pojmenovává nejčastější chyby ve slovní zásobě a výslovnosti. A zatřetí je zmíněn nedostatek vhodných moderních studijních materiálů a je zdůrazněna zásadní role e-learningového prostředí. V druhé části článku, s odkazem na průzkum a komentáře jeho respondentů, je probírána role učitele odborného jazyka.

\section{MEDIZINISCHE FACHSPRACHE - EINE HERAUSFORDERUNG FÜR LEHRER UND STUDENT}

Dieser Artikel befasst sich mit Englisch für spezifische Zwecke (ESP), konkret mit Englisch für medizinische Zwecke (EMP) und bringt dem Leser die Hauptprobleme nahe, mit welchen sich Lehrer und auch Studenten in den Kursen für medizinisches Englisch herumschlagen müssen. Der erste Teil des Beitrags widmet sich den wesentlichen Herausforderungen von ESP. Das erste Problem besteht im ungleichartigen Sprachniveau. Gruppen mit unterschiedlichen Sprachniveaus werden auf Grundlage von Einstufungstests dargestellt. Zum Zweiten geht es um die medizinische Terminologie. Der Artikel listet die häufigsten Fehler in Bezug auf Wortschatz und Aussprache auf und benennt sie. Drittens findet der Mangel an geeigneten modernen Studienmaterialien Erwähnung, wobei die grundsätzliche Rolle des ELearning-Ambientes hervorgehoben wird. Im zweiten Teil wird mit Hinweis auf die Forschung und die Kommentare der Befragten die Rolle des Lehrers der Fachsprache besprochen.

\section{SPECJALISTYCZNY MEDYCZNY JĘZYK ANGIELSKI - WYZWANIE DLA NAUCZYCIELA I STUDENTA}

Artykuł poświęcony jest językowi angielskiemu do celów specjalistycznych (ESP), konkretnie językowi angielskiemu do celów medycznych (EMP). Przedstawia najistotniejsze problemy, z którymi borykają się nauczyciele i studenci na kursach medycznego języka angielskiego. Pierwsza część opracowania dotyczy głównych wyzwań ESP. Pierwszy problem stanowi niejednorodny poziom językowy. Wielopoziomowe grupy pokazano na podstawie testu diagnostycznego. Po drugie to terminologia medyczna. W artykule wymieniono i nazwano najczęstsze błędy w słownictwie i wymowie. Po trzecie wskazano na niedobór odpowiednich nowoczesnych materiałów dydaktycznych i podkreślono zasadniczą rolę e-learningu. W drugiej części opracowania, powołując się na badania i komentarze ich respondentów, omówiono rolę nauczyciela specjalistycznego języka. 